\title{
Analysis of Treatment Result According to Operative Methods for Ranula
}

\author{
Tae Kyu Kang ${ }^{\mathbb{D}}$, Dong Young Kim ${ }^{\mathbb{D}}$, and Joo Hyun Woo ${ }^{\mathbb{D}}$ \\ Department of Otorhinolaryngology-Head and Neck Surgery, College of Medicine, Gachon University, Gil Medical Center, \\ Incheon, Korea
}

\author{
하마종의 수술 방법에 따른 치료 결과 분석 \\ 강태규 · 김동영 - 우주현 \\ 가천대학교 의과대학 길병원 이비인후과학교실
}

\author{
Received August 3, 2020 \\ Revised September 1, 2020 \\ Accepted September 16, 2020 \\ Address for correspondence \\ Joo Hyun Woo, MD, PhD \\ Department of Otorhinolaryngology- \\ Head and Neck Surgery, \\ College of Medicine, \\ Gachon University, \\ Gil Medical Center, \\ 21 Namdong-daero 774beon-gil, \\ Namdong-gu, Incheon 21565, Korea \\ Tel +82-32-460-3765 \\ Fax $+82-32-467-9044$ \\ E-mail woojh@gilhospital.com
}

Background and Objectives Ranula is a type of pseudocyst caused by the leakage of saliva from the mouth floor, mainly the sublingual gland, and is classified into a simple ranula and a plunging ranula according to its location clinically. Currently known surgical treatment for ranula includes incision and drainage, marsupialization, ranula excision, and sublingual gland resection. The aim of this study was to help decision making for the treatment of ranula by analyzing the complications including the recurrence rate of each treatment.

Subjects and Method We retrospectively reviewed 148 patients with ranula who had been treated from March 2000 to November 2019. All of the patients underwent one of the following treatments: incision and drainage, marsupialization, ranula excision, and sublingual gland resection. Complications including recurrence rate of each treatment were analyzed.

Results Of 144 patients, 92 were simple ranula and 52 were plunging ranula. Four patients underwent incision and drainage, 24 patients with marsupialization, 12 patients with ranula excision, and 104 patients with sublingual gland resection. The recurrence rates according to the treatment of total ranula were $100 \%, 29.2 \%, 50.0 \%$, and $8.7 \%$, respectively, in the order of incision and drainage, marsupialization, ranula excision, and sublingual gland resection. There were no complications other than the recurrence of the ranula.

Conclusion In the treatment of ranula, sublingual gland resection is considered to be the most appropriate method with minimal risk of complications and a low recurrence rate.

Korean J Otorhinolaryngol-Head Neck Surg 2021;64(11):806-10

Keywords Complication; Ranula; Recurrence; Sublingual gland; Surgery.

\section{서 론}

하마종은 구강저, 주로 설하선에서 유출된 점액에 의해 발 생하는 점액 낭종의 일종으로, 크기는 다양하게 나타나며 크 기가 큰 경우 연하 및 발음, 저작 시 문제를 야기할 수 있다. ${ }^{1)}$ 하마종은 임상적으로 발생 위치에 따라 단순 하마종과 몰입

This is an Open Access article distributed under the terms of the Creative Commons Attribution Non-Commercial License (https://creativecommons.org/licenses/by-nc/4.0) which permits unrestricted non-commercial use, distribution, and reproduction in any medium, provided the original work is properly cited.
성 하마종으로 나뉘며, 구강저에 국한되어 있는 단순 하마종 이 대부분을 차지하나 일부는 낭종이 악설골근 밑 악하선강 으로 확장되는 몰입성 하마종으로 나타난다. ${ }^{2,3)}$ 현재 알려진 하마종의 치료법은 경화요법, 절개배액술, 조대술, 낭종 절제 술, 설하선 절제술 등으로 다양하나,5) 가장 효과적인 치료법 에 대한 확실히 정립된 근거는 없다. 이에 본 저자들은 하마 종의 수술적 치료법에 따른 재발률을 포함한 합병증을 분석 하여 추후 하마종의 효과적인 치료법 선택에 도움이 되고자 하였다. 


\section{대상 및 방법}

본 연구에서는 2000년 3월 2019년 11월까지 가천대 길병원 이비인후과에서 하마종 진단 후 치료 받은 환자 148 명의 의 무기록을 후향적으로 분석하였다. 하마종의 종류에 따라 단 순 하마종(Fig. 1)과 몰입성 하마종(Fig. 2)으로 분류하였다. 신체검사에서 구강저에 압통을 동반하지 않은 둥근 지붕 형 태의 푸른빛을 띄는 종창을 보일 경우 단순 하마종으로, 하 마종이 악설골근 밑 악하선강으로 확장된 경우를 몰입성 하 마종으로 진단하였다. 몰입성 하마종이 의심되는 경우 전산 화단층촬영을 시행하여 몰입성 여부를 확인하였다.

하마종의 치료로서 절개배액술, 조대술, 낭종 절제술, 설하 선 절제술을 시행하였다. 절개배액술은 낭종에 단순 절개선 을 가한 후 내부의 점액을 배액하였다. 조대술은 구강에서 관 찰되는 낭종벽을 제거하고 내부의 점액을 배액한 후 제거된 낭종의 경계와 주변 점막을 봉합하여 하마종 저부와 구강저 점막이 연속되도록 하였다. ${ }^{6}$ 낭종 절제술은 하마종에 인접한 구강저 점막에 절개선을 가한 후 내부의 가성낭종을 적출하 고 점막을 다시 봉합해주는 방법으로,") 이 때 가능한 낭종이 손상되지 않게 보존하여 적출하였다. 설하선 절제술은 구강 저에 점막 절개를 가하여 하마종과 설하선을 노출시키고 하 마종과 함께 설하선을 적출한다. ${ }^{8)}$ 이 때 설신경과 악하선관 을 확인하여 보존하는 것이 중요하다. 몰입성 하마종의 경우 설하선과 연결된 하마종의 가성낭종을 최대한 제거하고 점 액을 배액시켰다. 단순 하마종은 국소마취 또는 전신마취하

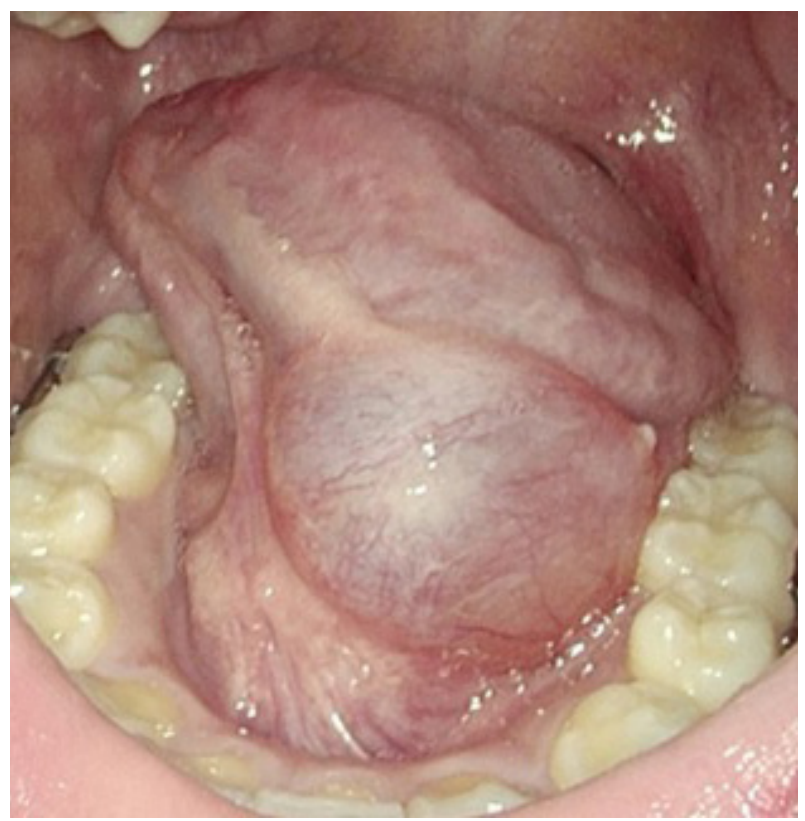

Fig. 1. Simple ranula. The blue translucent swelling exists in the left side of mouth floor.
절개배액, 조대술, 낭종 절제술, 설하선 절제술 중 한 가지 치 료를 시행하였으며, 몰입성 하마종 환자는 모두 전신마취하 설하선 절제술을 시행하였다. 수술은 동일한 원칙을 따르는 두 명의 술자에 의해 시행되었다.

하마종 재발을 포함한 합병증 발생 여부 파악을 위해 외래 추적 관찰 및 유선 면담을 실시하였으며, 단순 하마종 환자 중 조대술을 시행한 2 명과 몰입성 하마종 환자 중 설하선 절 제술을 시행한 2 명은 추적 관찰이 불가하여 재발 여부를 확 인할 수 없었다. 이를 제외한 144 명의 환자에서 하마종의 종 류와 수술방법에 따른 재발률과 합병증을 분석하였다.

범주형 변수들은 Fisher의 정확한 검정을 사용하였고, 연 속변수는 독립 $\mathrm{t}$-검정를 사용하여 분석하였다. 통계 분석은 SPSS 버전 20(IBM Corp., Armonk, NY, USA)을 사용하였 고 $p<0.05$ 일 때 통계적으로 유의미한 것으로 간주하였다.

본 연구는 본원의 임상시험연구심사위원회(Institutional Review Board)의 연구 승인을 받았다(IRB No. GCIRB 2020-208).

\section{결 과}

총 144 명의 환자 중 단순 하마종은 92 명, 몰입성 하마종은 52 명이었으며, 단순 하마종 중 남성은 34 명, 여성은 58명이었 고 몰입성 하마종의 경우 남성 26명, 여성 26명이었다. 평균 연 령은 22.1세로, 단순 하마종이 22.2세, 몰입성 하마종이 22.0 세였다. 평균 추적 관찰 기간은 5.36 개월로 단순 하마종은

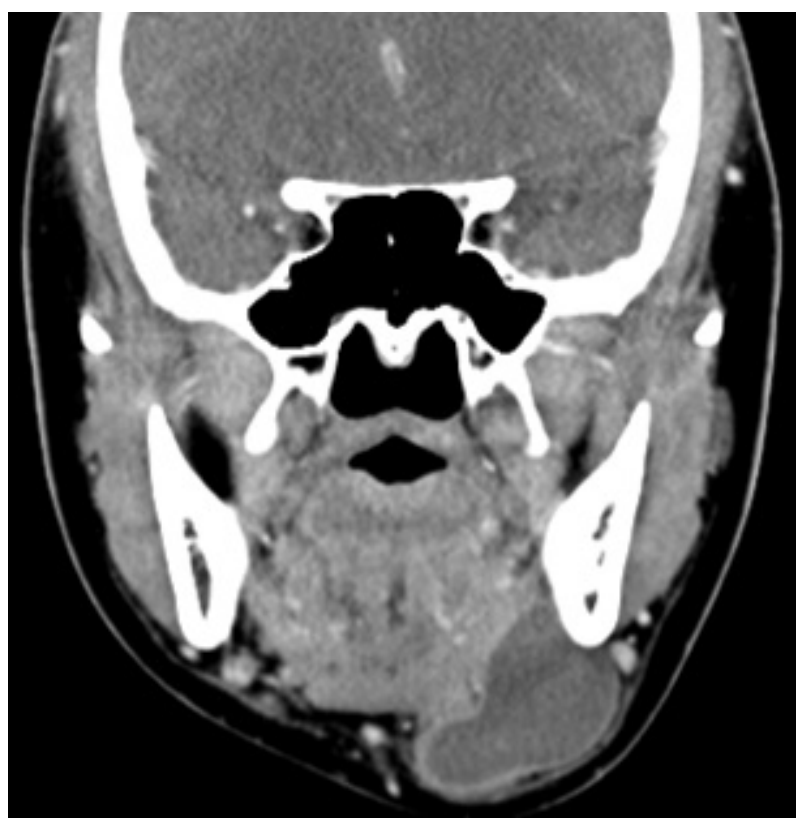

Fig. 2. Plunging ranula. In coronal image of enhanced CT, the cystic mass herniates through the mylohyoid muscle, into the left submandibular space. 
5.48개월, 몰입성 하마종은 5.15개월이었다(Table 1). 두 군 사이에 나이, 성별, 발생 위치, 추적 관찰 기간에 대한 유의한 차이는 없었다.

총 144 명의 환자 중 절개배액을 시행한 환자는 4 명, 조대술 은 24 명, 낭종 절제술 12 명, 설하선과 낭종 절제술을 함께 시 행한 환자는 104 명이었다. 단순 하마종 환자 92 명 중 4명은 절개배액, 24 명은 조대술, 12 명은 낭종 절제술, 52 명은 설하선 절제술을 시행하였으며, 몰입성 하마종 환자 52명은 모두 설 하선 절제술을 시행하였다.

전체 하마종의 치료법에 따른 재발률은 절개배액, 조대술, 낭종 절제술, 설하선 절제술 순서로 각각 $100 \%, 29.2 \%, 50.0 \%$, $8.7 \%$ 였다 $(p<0.001)$. 단순 하마종의 재발률은 상기 순서대로 각각 $100 \%, 29.2 \%, 50.0 \%, 11.5 \%$ 였으며 $(p<0.001)$, 몰입성 하 마종의 경우 설하선 절제술만 시행하였으며 재발률은 $5.8 \%$ 였다. 모든 환자에서 하마종의 재발 이외의 다른 합병증은 없 었다(Table 2).

\section{고 찰}

하마종은 주로 설하선이나 소타액선관의 손상으로 유출된 점액에 의해 발생하는 점액 낭종으로, 낭종의 위치에 따라 단 순 하마종과 몰입성 하마종으로 분류된다. ${ }^{5)}$ 하마종의 치료는

Table 1. Demographics of patient

\begin{tabular}{lcccc}
\hline & $\begin{array}{c}\text { Simple } \\
(\mathrm{n}=92)\end{array}$ & $\begin{array}{c}\text { Plunging } \\
(\mathrm{n}=52)\end{array}$ & $\begin{array}{c}\text { Total } \\
(\mathrm{n}=144)\end{array}$ & p value \\
\hline Age (years) & 22.2 & 22.0 & 22.1 & 0.9325 \\
& $( \pm 1.3)$ & $( \pm 1.1)$ & $( \pm 0.9)$ & \\
Sex & & & & 0.1595 \\
$\quad$ Male & 34 & 26 & 60 & \\
$\quad$ Female & 58 & 26 & 84 & \\
$\begin{array}{l}\text { Site } \\
\text { Right }\end{array}$ & & & & 0.2822 \\
$\quad$ Left & 49 & 23 & 72 & \\
$\quad$ Both & 41 & 29 & 70 & \\
$\begin{array}{l}\text { Follow up duration } \\
\text { (months) }\end{array}$ & 2 & 0 & 2 & \\
\hline Datare presented & 5.48 & 5.15 & 5.36 & 0.6981 \\
$( \pm 0.4)$ & $( \pm 0.8)$ & $( \pm 0.4)$ & \\
\hline
\end{tabular}

Data are presented as the mean \pm standard deviation
경화요법, 절개배액술, 조대술, 낭종 절제술, 설하선 절제술 등 다양한 방법이 제시되고 있다.

절개배액술은 매우 간편하여 특히 소아에서 선택적으로 시 행되곤 하나 73 100\%에 이르기까지 높은 재발률이 보고된 바 있다. ${ }^{9}$ 또한 조대술과 낭종 절제술의 재발률에 대해서도 많은 연구가 있어왔고, 각각 18 69\%, 37 62\%로 다양하게 보고되었으나 전반적으로 높은 재발률을 보였다. ${ }^{10-13)}$ 조대술 의 변형 형태로 점막을 제거하는 대신 하마종에 봉합사를 거 치하는 미세조대술이 소개되었다. ${ }^{14,15}$ 재발율은 0 25\%로 일 반 조대술에 비해서는 낮은 재발률을 보였지만 메타분석에 서 유의한 차이는 없는 것으로 나타났다. ${ }^{16)}$ 반면 설하선 절제 술의 경우 1.0 2.0\% 가량으로 현저하게 낮은 재발률을 보였 다. ${ }^{5,10,13)}$ 이와 같은 연구들은 하마종의 발생 원인인 설하선을 절제하는 것이 술후 재발률을 낮추는 데 현격히 기여함을 시 사하는 바이며, ${ }^{310,12)}$ 본 연구 결과 역시 이전 연구들과 비슷한 경향성을 갖는 것으로 확인되었다. 다만 이전 연구들이 설하 선 절제술의 수술적 접근 방법, 발생 가능한 합병증 및 재발 률의 분석에 대한 기술이 주를 이룬 반면, $2,17,18$ 본 연구는 설 하선 절제술뿐 아니라 다른 수술적 치료법의 적절한 병용 가 능성에 대해서도 확인할 수 있었다. 본 연구 결과 절개배액술 은 매우 간단한 치료법이나 재발률이 $100 \%$ 로 높아 일시적인 증상 완화는 가능하지만 하마종의 치료법으로 추천하기는 어려울 것으로 판단된다. 조대술과 낭종 절제술을 비교하였 을 때 조대술이 낭종 절제술에 비해 비교적 간단하며 덜 침 습적인 방법임에도 불구하고 재발률이 $29.2 \%$ 로 낭종 절제술 (50.0\%) 비해 유의미하게 낮았다. 조대술은 낭종벽을 제거하 고 내부의 점액을 배액한 후 제거된 낭종의 경계와 주변 점막 을 봉합하여 하마종 저부와 구강저 점막이 연속되도록 하는 방법이고, 낭종 절제술은 점액 낭종을 적출하고 점막을 다시 봉합해주는 방법이다. ${ }^{47)}$ 두 수술 방법 모두 설하선을 제거하 지 않는 방법으로, 잔존한 설하선에서 타액 배출이 다시 발생 할 수 있을 것으로 예상된다. 따라서 낭종을 적출하고 점막을 완전 봉합하는 낭종 절제술보다 배액통로를 남겨놓는 조대 술이 증상의 재발을 줄이는 데 효과적이며 이러한 이유로 조 대술이 낭종 절제술에 비해 재발율이 낮게 나타난 것이라 판

Table 2. Comparison of recurrence in the surgical treatment

\begin{tabular}{|c|c|c|c|c|c|c|c|c|c|}
\hline & \multicolumn{2}{|c|}{ Ranula } & \multirow{2}{*}{$p$} & \multicolumn{2}{|c|}{ Simple ranula } & \multirow{2}{*}{$p$} & \multicolumn{2}{|c|}{ Plunging ranula } & \multirow{2}{*}{$p$} \\
\hline & $\mathrm{n}$ & Recur (\%) & & $\mathrm{n}$ & Recur (\%) & & $n$ & Recur rate(\%) & \\
\hline$I \& D$ & 4 & $4(100)$ & $<0.001$ & 4 & $4(100)$ & $<0.001$ & 0 & - & - \\
\hline$M$ & 24 & $7(29.2)$ & & 24 & $7(29.2)$ & & 0 & - & \\
\hline RE & 12 & $6(50.0)$ & & 12 & $6(50.0)$ & & 0 & - & \\
\hline SLGR & 104 & $9(8.7)$ & & 52 & $6(11.5)$ & & 52 & $3(5.8)$ & \\
\hline
\end{tabular}

I\&D: incision and drainage, M: marsupialization, RE: ranula excision, SLGR: sublingual gland resection 
단된다. 설하선 절제술은 가장 침습적인 수술법으로, 전신마 취하 수술이 필요하며 설신경 및 악하선관의 손상 가능성이 있다. 또한 구강저의 점막손상으로 인한 반흔이 형성될 수 있 다. 그럼에도 불구하고, 이전 연구들에서 보고된 바에 의하면 설하선 절제술에 의한 혀의 감각저하 발생률은 $1.1 \sim 4.8 \%,{ }^{2,13)}$ 악하선관의 손상은 $0.7 \sim 2.82 \%{ }^{13,18}$ 로 다른 수술 방법에 비해 높지 않았으며, 본 연구에서는 재발 외의 합병증은 발생하지 않았기 때문에 합병증과 재발율을 고려하였을 때 설하선 절 제술은 가장 효과적인 치료법이라고 할 수 있다.

이번 연구에서 포함되지 않았지만 경화요법은 염증을 유발 할 수 있는 물질을 낭종 내부 공간에 주입하고 섬유화를 유 도하는 방법으로, 주로 벤질페니실린(benzylpenicillin)에서 배양된 streptococcus pyo-genes의 약독화 종으로부터 분리 한 OK-432(picibanil)를 사용한다. ${ }^{19)}$ 하마종에서는 OK-432 의 국소 염증 반응이 설하선 및 소타액선의 점액 생성을 저 해하고 흡수를 촉진시켜 낭종의 크기를 줄이는 것으로 생각 되며, 이전의 연구들에 의하면 치료 결과는 59 74\%로 나타 난다. ${ }^{19,20)}$ 하지만 하마종은 상피세포가 존재하지 않기 때문에 주요 작용 기전이 낭종의 상피세포에서 염증반응을 유발하는 경화요법과는 상호 간에 이론적 괴리가 있다. 또한 $\mathrm{OK}-432$ 는 더 이상 국내에서 시판되지 않아 임상에서 사용이 불가하다. OK-432 대신 99\% 알코올을 이용하여 경화요법을 시행하기 도 하나 작용 기전은 동일하다.

이번 연구에서는 각 수술 방법에 따른 표본의 수가 적고 균등하지 않아 각 수술법의 효과를 비교하는 데 제한이 있 었다. 더우기 몰입성 하마종은 모든 예에서 설하선 절제술만 시행되었기 때문에 다른 수술법과 비교할 수 없었다. 또한 본 연구에서 분석한 각 증례의 추적 기간이 일정하지 않고 짧아 정확한 합병증 발생 여부 파악에 한계가 있었다. 추후 지속적 으로 증례를 수집하여 표본 수를 늘리고 최소 추적 기간을 설정하여 상기 한계점을 보완한 추가 연구가 필요하다.

이번 연구 결과를 고려하였을 때 단순 하마종의 경우 조대 술을 시행하는 것도 고려할 수 있지만, 낭종 절제술과 설하 선 절제술을 동시에 시행할 때 가장 좋은 효과를 기대할 수 있다. 몰입성 하마종은 경구강 접근법으로 설하선과 하마종 을 절제하고 점액을 배액하는 것으로 좋은 효과를 기대할 수 있다.

\section{Acknowledgments}

None.

\section{Author Contribution}

Conceptualization: Joo Hyun Woo, Dong Young Kim. Data curation: Joo Hyun Woo, Tae Kyu Kang. Formal analysis: Joo Hyun Woo, Tae Kyu Kang. Investigation: Joo Hyun Woo, Tae Kyu Kang.
Methodology: Joo Hyun Woo, Dong Young Kim. Resources: Joo Hyun Woo, Dong Young Kim. Writing_original draft: Joo Hyun Woo, Tae Kyu Kang. Writing - review \& editing: Joo Hyun Woo, Tae Kyu Kang.

\section{ORCIDs}

Joo Hyun Woo

Tae Kyu Kang

Dong Young Kim

https://orcid.org/0000-0002-8584-563X

https://orcid.org/0000-0002-7274-0476

https://orcid.org/0000-0001-5485-7198

\section{REFERENCES}

1) Kim BH, Ryu YJ, Jung YH. Pathophysiology and management of the ranula. Korean J Otorhinolaryngol-Head Neck Surg 2016;59(5): $339-45$.

2) Ko SH, Kang HJ, Jung SM, Ji YB, Song CM, Tae K. Significance of sublingual gland excision in surgical treatment of ranula. Korean J Otorhinolaryngol-Head Neck Surg 2017;60(7):352-5.

3) Hong KH, Yang YS, Park HT, Hwang BE, Lee KS, Lim SH, et al. Surgical results of the intraoral removal for plunging ranula. Korean J Otorhinolaryngol-Head Neck Surg 2010;53(11):702-5.

4) McGurk M, Eyeson J, Thomas B, Harrison JD. Conservative treatment of oral ranula by excision with minimal excision of the sublingual gland: Histological support for a traumatic etiology. J Oral Maxillofac Surg 2008;66(10):2050-7.

5) Harrison JD. Modern management and pathophysiology of ranula: Literature review. Head Neck 2010;32(10):1310-20.

6) Na HJ, Lee JH, Kim SO, Song JS, Kim SH, Choi HJ, et al. Marsupialization of ranula. J Korean Acad Pediatr Dent 2011;38(1): 88-94.

7) Morita Y, Sato K, Kawana M, Takahasi S, Ikarashi F. Treatment of ranula--excision of the sublingual gland versus marsupialization. Auris Nasus Larynx 2003;30(3):311-4.

8) Yoo BY, Yoo JK, Kim DK, Lee EJ, Park JS. Intraoral approach in plunging ranula. Korean J Otolaryngol-Head Neck Surg 2005; 48(4):516-9.

9) Zhi K, Wen Y, Zhou H. Management of the pediatric plunging ranula: Results of 15 years' clinical experience. Oral Surg Oral Med Oral Pathol Oral Radiol Endod 2009;107(4):499-502.

10) Zhao YF, Jia Y, Chen XM, Zhang WF. Clinical review of 580 ranulas. Oral Surg Oral Med Oral Pathol Oral Radiol Endod 2004; 98(3):281-7.

11) Lee HM, Lee JH, Cho JG, Song JS, Lee SH, Woo JS, et al. Clinical analysis of the 22 cases of plunging ranula. Korean J Otolaryngol 2003;46(9):764-8

12) Lee DH, Yoon TM, Lee JK, Lim SC. Treatment outcomes of the intraoral approach for a simple ranula. Oral Surg Oral Med Oral Pathol Oral Radiol 2015;119(4):e223-5.

13) Patel MR, Deal AM, Shockley WW. Oral and plunging ranulas: What is the most effective treatment? Laryngoscope 2009;119(8): $1501-9$.

14) Woo SH, Chi JH, Kim BH, Kwon SK. Treatment of intraoral ranulas with micromarsupialization: Clinical outcomes and safety from a phase II clinical trial. Head Neck 2015;37(2):197-201.

15) Aluko-Olokun B, Olaitan AA. Ranula decompression using stitch and stab method: The aluko technique. J Maxillofac Oral Surg 2017;16(2):192-6.

16) Chung YS, Cho Y, Kim BH. Comparison of outcomes of treatment for ranula: A proportion meta-analysis. Br J Oral Maxillofac Surg 2019;57(7):620-6.

17) Mortellaro C, Dall'Oca S, Lucchina AG, Castiglia A, Farronato G, Fenini E, et al. Sublingual ranula: A closer look to its surgical management. J Craniofac Surg 2008;19(1):286-90. 
18) Zhao YF, Jia J, Jia Y. Complications associated with surgical management of ranulas. J Oral Maxillofac Surg 2005;63(1):51-4.

19) Roh JL. Primary treatment of ranula with intracystic injection of OK-432. Laryngoscope 2006;116(2):169-72.
20) Kim MG, Cho EY, Song JW. The effect of the sclerotherapy of plunging ranula with the use of picibanil. Korean J OtolaryngolHead Neck Surg 2004;47(12):1278-81. 